\title{
Introduction: The encyclopaedic tradition
}

For his amusement [George Fewkoombey] read an old tattered volume of the Encyclopaedia Britannica which he had found in the lavatory. Only about half the volume was there and it was not the first volume. Nevertheless one could learn quite a lot out of it, even if it did not suffice for a complete education. But who had that nowadays?

Bertolt Brecht, Threepenny Novel, trans. Desmond I. Vesey, London: Penguin, I96I, p. 62.

In Western culture, the concept of an encyclopaedia has come to symbolise universal or total knowledge. As Brecht's pathetic character attests, such works have excited great expectations, and equally great disappointments. The story of encyclopaedias is one of grand ideals and mixed achievements. Some famous writers have fashioned noble visions of the cultural role performed by these works. Gottfried Wilhelm Leibniz imagined an encyclopaedia that would systematically condense all knowledge in a universal symbolic language. Diderot and d'Alembert saw the Encyclopédie as a summary of progressive thought, and a place in which readers, by exploring cross-references, might participate in an ongoing conversation. Samuel Taylor Coleridge conceived the Encyclopaedia Metropolitana as an antidote to some of the assumptions he detected in the French publication: Coleridge sought to restore the proper philosophical hierarchy of the sciences and to show that intellectual revolutions were more complex, and rarer, than political ones. The enormously successful Encyclopaedia Britannica, first published in I77I, came to be regarded as an emblem of the British Empire: in the early nineteenth century it was spoken of as the 'national Encyclopaedia' and seen as a carrier of British values to the colonies. ${ }^{1}$ In the early twentieth century, H. G. Wells looked to a grand 'World Encyclopaedia' as the repository of a 'World Brain'. Such a work would facilitate international peace and co-operation. Wells prophesied the modern 'age of information', and his

1 F. Horner to Napier, 5 January I8 I 5, BL, Add. MS. 34,6 I I, f. I 58; J. S. Mill to Napier, 8 July I 830, BL, Add. MS. 34,6I4, f. 356. 
optimism exceeded that of its most uncritical champions: 'There will not be an illiterate left in the world. There will hardly be an uninformed or misinformed person. And the brain of the whole mental network will be the Permanent World Encyclopaedia.'

The philosopher Karl Popper included encyclopaedias in his category of a 'third world' of objective knowledge residing in libraries. This was a world of knowledge separate from the first world of external phenomena and the second world of sensation and cognition. On this view, encyclopaedias, once published, became 'third worlds' of codified, rational knowledge. Popper speculated on the possibility of recovering knowledge, once held in minds of individuals, from this archive of knowledge preserved in books (and encyclopaedias). Imagine, he said, a scenario in which 'all our machines and tools are destroyed, and all our subjective learning, including the knowledge of machines and tools, and how to use them. But libraries and our capacity to learn from them survive. Clearly, after much suffering, our world may get going again.' To those who objected that all the concepts, theories and arguments recorded in books were symbolic expressions of subjective mental states rather than independent entities, he posed a change to the first scenario: suppose, instead, that 'all libraries are destroyed also'. ${ }^{3}$ For Popper, the stark contrast here between the presence and absence of libraries was eloquent testimony to the importance of collections of knowledge beyond that possessed by any individual mind.

In the Western tradition there has been a conviction that it is possible, and worthwhile, to collate knowledge that is representative of some larger whole. The ideal imagined here is a work that summarises and organises the knowledge contained in many books. This reflects a legacy from the middle ages, one informed by a view of the world as a mirror of the divine mind. Encyclopaedias of the late middle ages typically sought to include the most highly valued knowledge, that which was thought to contain truths about God's two books: the Bible and Nature. Encyclopaedias thus recorded humanity's efforts in achieving the knowledge that God had intended for His rational creatures. By the twelfth century, scholastic theologians were confident that human knowledge could, potentially, reach divine truths about morality and the physical world. Indeed, they believed that in the prelapsarian state Adam possessed this knowledge; but after the Fall it was gradually lost, in spite of the prodigious memories of the patriarchs who inherited parts of it from him. Writers such as Bonaventura and Hugh of St Victor

2 Wells, World Brain, 48, 5I, 57. This reprints three papers published between I 936 and I937; also his Work, Wealth and Happiness of Mankind, 763-76; Burr, 'The Encyclopaedia Britannica', I08-9 regarded the Britannica as closer to international status than the French Grande Encyclopédie (1886-1903).

3 Popper, Objective Knowledge, I07-8 (emphasis in original). 
considered the quest for knowledge of the natural world as a crucial part of man's attempt to be again at one with God. ${ }^{4}$ After the Protestant Reformation this theme was firmly linked to empirical scientific inquiry, most obviously by Francis Bacon, who made the search for natural knowledge a precondition for spiritual redemption. In this context, encyclopaedias were safeguards against losing again the knowledge that had been regained since the Fall. Johann Heinrich Alsted (I588-1638) published Encyclopaedia Septem Tomis Distincta in I630, considered as the last and best of the Latin neo-scholastic encyclopaedias. ${ }^{5}$ This was preceded by his Diatribe de Mille Annis Apocalypticis (I627), in which he predicted the

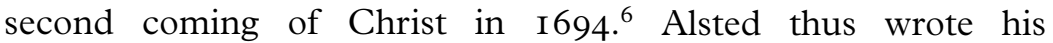
Encyclopaedia on the assumption that the world would soon end, and that the stock of knowledge should be gathered together as part of a communal accounting for human endeavours since the loss of Eden.

Diderot's vision of the Encyclopédie is a secular version of these earlier notions. In his entry on the concept of 'Encyclopaedia' (volume v, I755) he regarded the work in which he was then engaged as a time capsule of the Enlightenment. In the event of a catastrophe, it would be a summary of intellectual accomplishments to be reactivated by a later age. This is the most powerful encyclopaedic vision: a work containing the collective knowledge of a community which might be put together again if all other books were lost. It is worth noting how this notion of encyclopaedias as potential saviours of knowledge and culture - as seen in the views of Diderot and Popper - conflicts with the corrosive thoughts of the twentiethcentury Argentinian writer, Jorge Luis Borges, in his short stories, such as those collected under the title Labyrinths. In 'The Library of Babel', Borges contemplates an eternally existing library, stocked with books on a version of the principle of plenitude: namely, 'it suffices that a book be possible for it to exist'. Hence the library holds not only all books but, for example, 'the translation of every book in all languages'; not only a 'faithful catalogue of the Library', but 'thousands of false catalogues', and so on. Borges conjures up the reactions of the inhabitants to this prospect - joy, at first, at the thought of being 'masters of an intact and secret treasure', and then horror at the realisation that they could never read even a tiny fraction of its contents. In their desperation, some are soon possessed by the belief that there must somewhere exist on the innumerable shelves a 'total book' - a 'perfect compendium of all the rest' ${ }^{7}$

${ }^{4}$ Harrison, The Bible, Protestantism, 56-63.

5 Published in four folio volumes, Herborn: G. Corvinus, I630.

6 Translated as The Beloved City or, The Saints reign on Earth a thousand yeares, London, I643; Loemker, 'Leibniz and the Herborn Encyclopaedists', 33 I.

7 Borges, Labyrinths, 83-4. 
This can be read as a malicious satire of the encyclopaedic tradition and its promise of a book of universal knowledge. Unlike Popper's 'third world' archive, or Diderot's Encyclopédie, Borges' library contains all knowledge, but it cannot be accessed; if destroyed, the collective knowledge it holds could not be restored by human beings. In another story, Borges seems to seal this demolition. He sets up a scene guaranteed to excite those who see libraries and encyclopaedic collections as treasure houses, as keys to the civilisations that produced them. An explorer looking for a lost city makes a discovery: 'The damp path zigzagged like those of my childhood. We came to a library of Eastern and Western books. I recognized bound in yellow silk several volumes of the Lost Encyclopaedia, edited by the Third Emperor of the Luminous Dynasty but never printed.' Borges then deflates expectations by remarking that for the author of this work, the writing of an encyclopaedia and the construction of a labyrinth were the same task: both were places in which one became lost. ${ }^{8}$

Encyclopaedic dreams have almost always outrun achievements. In November I6I9 the young René Descartes had a dream in which he contemplated an encyclopaedia that displayed the systematic relations of all the sciences, one that contained complete knowledge, as God possessed it. But Descartes awoke with this encyclopaedia unfinished. ${ }^{9}$ Bacon's plans for the reform of knowledge inspired encyclopaedias, but neither he nor Leibniz (who had his own plan) ever seriously began his own. Various writers such as Vincenzo Coronelli (incomplete work between I 70I and I 706) and Oliver Goldsmith intended to compile an encyclopaedia. ${ }^{10}$ Some other large projects were left unfinished, stranded at some volume before the end of the alphabet. Perhaps the most striking example of unrealised vision is the German encyclopaedia started in I 8 I 8 and still unfinished (at 167 volumes) in I889, when it was abandoned by its new publisher, Friedrich A. Brockhaus. The original editors, Johann Ersch and Johann Gruber, had sought to create a work that would be a library of libraries. ${ }^{11}$ But even completed encyclopaedias bear the traces of failure just averted: in most cases, a rough count of the number of entries per letter reveals a decline in intensity, and perhaps enthusiasm, towards the end of the alphabet.

8 Ibid., 49 and also 28, 3I. Umberto Eco gives another treatment of this theme in The Name of the Rose.

9 Maritain, Dream of Descartes, ch. I; Rodis-Lewis, 'Descartes' Life', 3 I-2. For comment on these dreams, Gaukroger, Descartes, I06-9.

10 Coronelli's Biblioteca Universale reached volume 7 of a planned 40; Tonelli, Short-title List, I4; Goldsmith, Works, ed. Gibbs, vol. I, 37, 47 I; Collison, Encyclopaedias, I09. In the early I 700s William Hogarth's father had drafts of a huge dictionary for which he could not find a publisher: Uglow, Hogarth, 27.

11 Ersch and Gruber, Allgemeine Encyclopädie der Wissenschaften und Künste; Lenz, Kleine Geschichte grosse Lexika; Merz, History of European Thought, vol. I, 34-8; Collison, Encyclopaedias, I79-80. 
Notoriously, the first Encyclopaedia Britannica spent the first of its three volumes dealing with $\mathrm{A}-\mathrm{B}$, while the last packed in $\mathrm{M}-\mathrm{Z}$.

\section{Medieval and Renaissance encyclopaedias}

What has counted as a completed encyclopaedia varies enormously. In fact, anxiety about the hubris of the quest for total knowledge - as reflected by Borges - is a modern phenomenon. Isidore of Seville's Etymologiae (completed by Braulio, his secretary, after Isidore died in AD 636) was seen as a compendium of all worthwhile knowledge, based on the Roman circle of the liberal arts but also including information on geography, navigation, food and so on. ${ }^{12}$ In the high middle ages, commonly regarded as the apex of encyclopaedism, a complete collection of knowledge did not seem an impossible dream. The most famous of the medieval works was the Speculum Maius ('The greater mirror'), completed by the Dominican friar, Vincent of Beauvais (who died in I264), around I250. It comprised three books, or mirrors - of nature, of history and of doctrine. The last book, the 'Mirror of Doctrine', covered all fields of learning, including the liberal and mechanical arts, mathematics and natural philosophy. ${ }^{13}$ The image of the mirror betrays the assumption, and the confidence, that an encyclopaedia, a collation of textual material, could genuinely reflect the universal structures of the world. ${ }^{14}$ In claiming to embrace the circle of knowledge - or, as Vincent said, 'all that is worthy of contemplation'15 - this work was not haunted by the prospect of being quickly rendered obsolete by the rapid progress of knowledge.

This outlook has to be understood within the theological framework that regarded true knowledge, once found, as a divine and unchanging gift. Cassiodorus (480-575), probably the first Christian to use the term 'seven liberal arts', followed Augustine in 'holding that the arts were perfect, eternal, unchanging archetypes of knowledge'. In his De Institutis Literarum Sacrarum, he affirmed that: 'They are neither increased by expansion nor diminished by contraction nor modified by any changes, but abide in their own proper nature and observe their own rules with indisputable constancy.' ${ }^{16}$ In this respect, the encyclopaedic works of Western

12 Collison, Encyclopaedias, 23; Brehaut, Encyclopedist of the Dark Ages; Arnar, Encyclopaedism, ix.

13 Thorndike, History of Magic, vol. II, 457-60.

14 McArthur, Worlds of Reference, 67; Moss, Printed Commonplace-books, 27-32. For the related concept of theatrum mundi, and its use in the Renaissance, see Blair, Theater of Nature, ch. 5. On assumptions about 'resemblance' underlying these metaphors, Foucault, Order of Things, ch. 2.

15 Cited in Lawler, 'Encyclopaedias and Dictionaries'.

16 Moran, Philosophy of John Scotus Eriugena, I29 on Cassiodorus' De Artibus et Discipliniis Liberalium Literatim; Abelson, Seven Liberal Arts, 9; also Cahn, 'Medieval Landscape and the Encyclopedic Tradition'. 
Christian culture, from Isidore's to the compendia of the liberal arts by early scholastics such as Peter Abelard (I079-I I42) and Hugh of St Victor (I096-I I4I), to the Speculum Maius of Vincent of Beauvais, shared the mission of conserving and cultivating the best of knowledge, both divine and human. In fact, the raison d'être of these works was similar to that of the more massive compilations produced in China from the third century AD. In both cultures, this type of work was not intended to report new findings but rather to collect, arrange and transmit old knowledge. Such works were, in principle, 'directed not toward the future but backward toward the past', although this did not preclude present uses. Thus the Western encyclopaedias often incorporated the subjects of the university curriculum, and the Chinese ones acted as stable compendia for civil service exams. ${ }^{17}$

None of these medieval works carried the title of 'encyclopaedia'. This Latinised word - as used by Quintilian - first appeared in titles of compendia from the sixteenth century, where it referred to the circle or round of education. ${ }^{18}$ Paul Scalich's Encyclopaedia, seu Orbis Disciplinarum, tam sacrum quam profanarum, Epistemon (Basel, I 559), is now regarded as the first clear example. Its subtitle indicates the 'orbis doctrinae' - as the Greek circle of studies was construed in the Latin world - which was influentially summarised by Marcus Terentius Varro's (I I6-27 BC) Disciplinarum Libri Novem (circa 50 BC). Varro wrote treatises on subjects later grouped as the trivium (grammar, logic, rhetoric) and quadrivium (geometry, arithmetic, astronomy, music), as well as on medicine and architecture. ${ }^{19}$ Before it was lost during the middle ages, this work influenced other compendia, such as Martianus Capella's De Nuptiis Philologiae et Mercurii ('The marriage of Philology and Mercury'), an early fifth-century compendium of subjects later used as a handbook of the seven liberal arts. ${ }^{20}$ Indeed, this concept of a set of worthy subjects, whether or not accompanied by the word 'encyclopaedia', is crucial to an understanding of how compilers could contemplate a comprehensive survey with equanimity. They did not seek to cover all knowledge, nor did they provide an

17 Bauer, 'Encyclopaedia in China', 665; Guy, Emperor's Four Treasures. For other comparisons, Burke, 'History of Encyclopaedias'.

18 For the derivation and meaning of 'enkyklios paideia', Fowler, 'Encyclopaedias'; see the chronology of titles to I900 in Cahiers d'Histoire Mondiale, 9 (I966), 453-56; Shackleton, 'Encyclopaedic Spirit', 378-8I for the more frequent use of the word in titles from the late I550s.

19 Thus Varro included nine subjects, including the practical arts of medicine and agriculture, dropped by later writers; Abelson, Seven Liberal Arts, 4; Steinberg, 'Encyclopaedias', 6; Collison, Encyclopaedias, 23; North, 'Art of Knowing Everything'.

20 After two introductory books, the remaining seven deal with each of these subjects; Stahl, Capella, vol. II and Roman Science, ch. I I. 
exhaustive treatment of any subjects, but rather a summary of the most significant branches of knowledge from an esteemed course of study. ${ }^{21}$

One of the most successful examples of such a work from the Renaissance is the Margarita Philosophica ('The philosophic pearl'), first published in Freiburg in I496, by the Carthusian prior, Gregor Reisch (see figure I). In a single book, Reisch sought to summarise the circle of arts and sciences, or at least those covered in the university curriculum of his day. Divided into twelve books, it summarised the trivium and quadrivium, as well as natural and moral philosophy. After the first edition this work went through ten editions between 1503 and $1599 .^{22}$ Latin compendia such as this gave pedagogical summaries in essay form of the major subjects from what was sometimes called the 'encyclopedy' - meaning the course of learning appropriate to the educated person. In fact, as late as the seventeenth century, the term 'encyclopedy' usually referred not to a single work but to the range of subjects an educated person should pursue. In his Glossographia of I656, Thomas Blount (I6 I 8-79) defined the 'encyclopedy' as 'that learning which comprehends all Liberal Sciences; an Art that comprehends all others, the perfection of all knowledge'. ${ }^{23}$ The description of the course of lectures given by Robert Greene at Clare College, Cambridge in 1707 was published as Encyclopaedia, [in Greek]; or a method of instructing pupils. Greene referred to this as a 'Circle of Studies', although it is evident that the appropriate subjects (and their sequence) were disputed: he anticipated complaints that 'there are not Classicks enough taught in the Method', arguing that these were taught in the schools prior to university. This allowed him to include, in the fourth year, the Mechanicks and Astronomy recently 'given us by Sir Isaac Newton, Hugens [sic], Wallis and others', in spite of his own religious reservations about Newtonian philosophy. ${ }^{24}$ All these usages referred to a course of education in the arts and sciences, but not to a single work..$^{25}$

21 For informed surveys, Lyons, 'Encyclopaedia', Read, 'Encyclopaedias and Dictionaries'; Salsano, 'Enciclopedia', and, more specifically, Sharratt, Humanism and the Encyclopedia.

22 Anon., List of Editions of the Margarita Philosophica I 503-I 599.

23 Blount, 'Encyclopedy' and 'To the Reader', Glossographia. Blount was a Roman Catholic and loyalist.

${ }^{24}$ Greene, Encyclopaedia; Gascoigne, Cambridge in the Enlightenment, I 59, 167.

25 This was still the only sense given of 'encyclopaedia' in Johnson's Dictionary of I755. Thomas Hobbes used 'encyclopaedia' in I686 when mentioning the Greek idea of 'the whole of learning'. In his Dictionnaire, Furetière defined it as referring to universal knowledge and the chain of sciences, but also said that the word is 'archaic and used only in humorous writing'; cited in Shackleton, 'Encyclopaedic Spirit', 378; Furetière, Dictionnaire, vol. I for 'dictionnaire' and vol. II for 'encyclopaedia'. 
Cambridge University Press

978-0-521-65191-2 - Encyclopaedic Visions: Scientific Dictionaries and Enlightenment Culture Richard Yeo

Figure I The circle of the sciences. Gregor Reisch, Margarita Philosophica, Freiburg, I 503.

\section{zzargartiapbiloropinira}

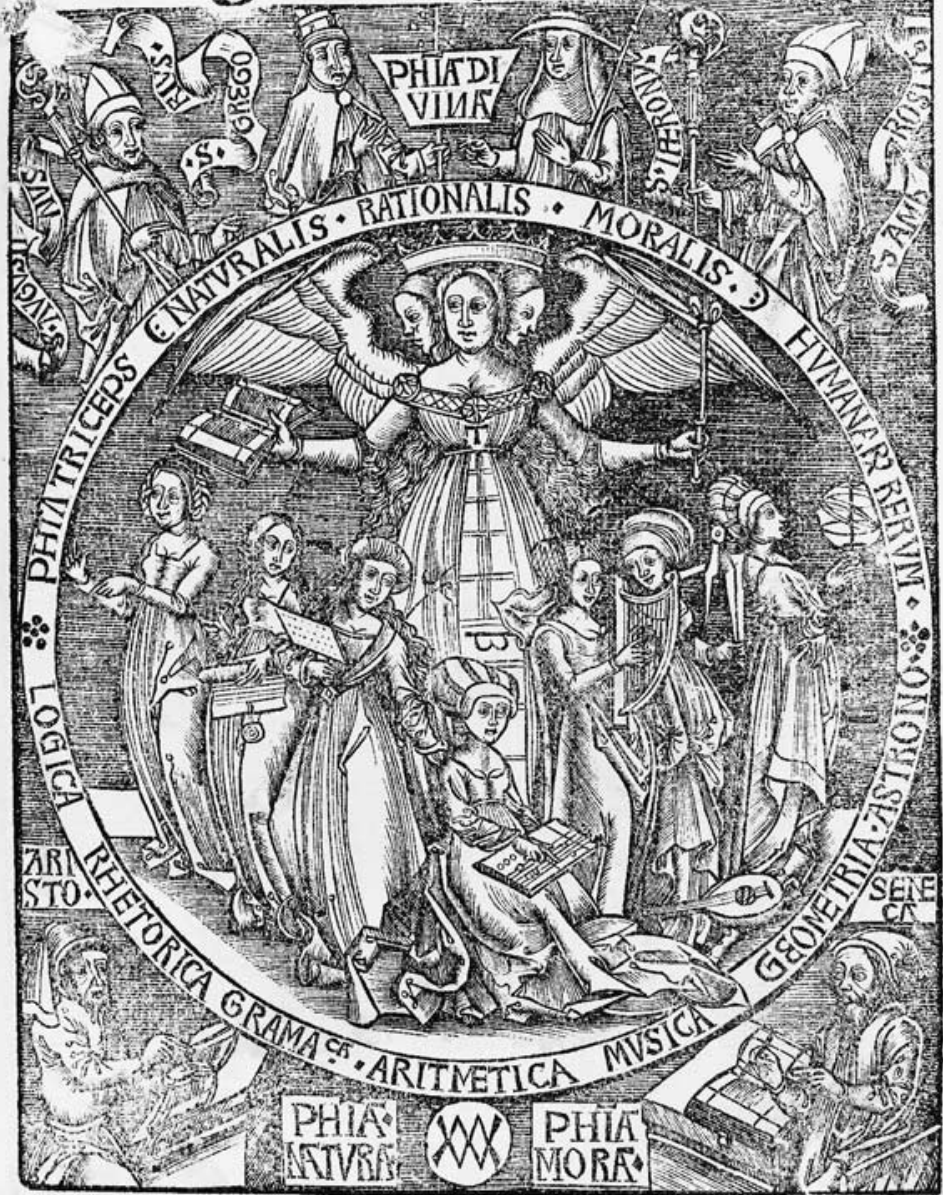


These last examples indicate how the content of this encyclopaedic round of study was a matter of contention, with new subjects pushing for inclusion. This is discernible in the comparison of Alsted's works of I620 and 1630. His Cursus Philosophici Encyclopaedia (I620), although broad, was limited to 'philosophy' understood as the disciplines of the arts faculty. This work included the liberal arts such as rhetoric and logic, as well as some subjects of natural philosophy, such as optics, and also both theoretical and practical mechanics. ${ }^{26} \mathrm{~A}$ decade later, his Encyclopaedia was even broader, incorporating the subjects of the three 'superior' faculties of theology, law and medicine, with the addition of the mechanical arts. Here Alsted conceived the encyclopaedia as the 'methodological understanding of everything than man must learn in this life'. ${ }^{27}$ But while this notion still reflected the idea of an encyclopaedia as a course of learning that might realistically be pursued by an individual, the expanding content betrayed a shift towards the goal of near-exhaustive coverage. ${ }^{28}$ Referring to the voluminous Latin compendia produced by the seventeenth-century German 'polyhistors' who revelled in this impulse towards 'total' knowledge, one scholar has suggested that the 'Encyclopedism' of this period is 'harder than humanism to define'. ${ }^{29}$

From the early modern period the encyclopaedic project showed signs of exploding under the strain of the content it sought to embrace. As Neil Kenny has demonstrated, there was a flourishing of encyclopaedic miscellanies that either challenged, or simply sat awkwardly beside, the philosophically or pedagogically informed conception of these works that reached a culmination in Alsted. Michel Montaigne questioned the possibility of a conceptual unity and revelled in the fragmentary and provisional character of knowledge; compilers such as Béroalde de Verville (in his later writings) indulged in the thrill of unusual juxtapositions and the cornucopia of curious information gathered from different sources. ${ }^{30}$ Thus, just as Alsted's solid tomes appeared, the very nature and purpose of such

26 Alsted, Cursus Philosophici Encyclopaedia. This edition (Herborn, I620) at the Beinecke Library $(1983+24)$ is one volume quarto, about six inches thick and paginated within each separate part.

27 Cited in Kenny, Palace of Secrets, I 5; Arnar, Encyclopedism, 8; This statement occurs in the first of a series of diagrams of knowledge given in Book I. Alsted's work comprised seven tomes (or books) covering a total of thirty-four subjects. 'Physica', 'Cosmographica' and 'Optica' are among subjects treated in Book III; the 'Artes Mechanicae' are in Book vi. See Cole, Neglected Educator, for translation of parts of Alsted's Encyclopaedia.

${ }^{28}$ Kenny, Palace of Secrets, 32. See Schmidt-Biggemann, Topica Universalis, 100-54 on Alsted as responding to the collapse of the scholastic synthesis as well as the expansion of new knowledge and methods of inquiry since the early i6oos.

29 Grafton, 'World of Polyhistors', 37.

${ }^{30}$ Kenny, Palace of Secrets, ch. 4; Blair, 'Bodin, Montaigne and the Role of Disciplinary Boundaries' for contrasts between Bodin and Montaigne. 
encyclopaedic collections came under more intense scrutiny. By the early I60os this was accentuated by the implications of Bacon's critique of scholastic philosophy. In stressing that knowledge was to be found in the world, and not merely in texts, Bacon opened the floodgates: his call for the collection of new facts and observations stimulated an expectation of constant revision of current doctrines, making the concept of a stable encyclopaedia more problematic than it ever had been. ${ }^{31}$ Significantly, in his own unfinished Sylva Sylvarum (published posthumously in I626), which began a collection of data in natural history, Bacon confessed that the contents of this 'may seem an Indigested Heap of Particulars'. ${ }^{32}$ An example of the attempt to squeeze an expanded array of subjects into the traditional circle of sciences is Richard Blome's Gentleman's Recreations: in two Parts (I686). Its subtitle reveals an audacious attempt at clever packaging, a combination of the liberal and practical subjects appropriate for the landed gentry and other aspirants: 'The First being an Encyclopedy of the Arts and Sciences ... The Second Part Treats of Horsemanship' ${ }^{33}$ (see figure 2).

Another feature of Renaissance encyclopaedism was the idea that an encyclopaedic representation of knowledge could take the form of a physical display - a library, a garden, a cabinet of curiosity, a museum. Thus the Jesuit polymath, Athanasius Kircher (I602-80) referred to his Wunderkammer situated in the College of Rome as his 'enciclopedia concreta'. ${ }^{34}$ The goal of assembling a universal bibliography could also be considered as part of this broad encyclopaedic quest; and in the works of François de La Croix du Maine (I 584) and Gabriel Naudé (I627) it encouraged a quest for the perfect library, either actual or imagined, organised on a plan that reflected the circle of learning. ${ }^{35}$ Underlying these activities was a common aim to reflect an objective order in the categories of nature and in the disciplines of the arts and sciences employed to understand God's world - so that this could be recalled and transmitted. Furthermore, all these attempts to gather objects in one place were stimulated by the biblical notion of a loss of knowledge and innocence after the Fall. ${ }^{36}$ Protestant theologians, in particular, were exercised by the hope of restoring former pristine knowledge of nature, languages and morality - a vision power-

31 Daston, 'Factual Sensibility' and 'Baconian Facts'; Dear, Discipline and Experience, I 8-2I. $\quad 32$ Cited in Kenny, Palace of Secrets, 29.

33 Blome, Gentleman's Recreations, vol. I. By the second edition of I7Io this had grown to three parts. See Hunter, 'The Crown and the New Science' for Blome's audience.

${ }^{34}$ Kircher cited in Findlen, Possessing Nature, 55, 79-93, on non-textual ideas of the 'encyclopedia of knowledge'. $\quad 35$ Chartier, Order of Books, ch. 3.

36 Bennett and Mandelbrote, The Garden, 7-I I on schemes for perfect collections of plants, animals or books as expressions of this vision. 